\title{
NONPREFERENCE OF WHITEFLY FOR OVIPOSITION IN TOMATO GENOTYPES ${ }^{1}$
}

\author{
Luciana Cláudia Toscano,4*; Arlindo Leal Boiça Jr. ${ }^{2}$; Wilson Itamar Maruyama ${ }^{3}$ \\ ${ }^{2}$ Depto. de Fitossanidade - UNESP/FCAV, Via de Acesso Prof. Paulo Donato Castellane, s/n - CEP: 14884-900 - \\ Jaboticabal, SP. \\ ${ }^{3}$ Depto. de Ciências Exatas - UNESP/FCAV. \\ ${ }^{4}$ FAPESP Fellow. \\ ${ }^{*}$ Corresponding author <lucianaclaudiatoscano@yahoo.com.br>
}

ABSTRACT: The silverleaf whitefly is one of most important pests of tomato (Lycopersicon spp.). The use of host plant resistance to control this insect is an interesting, potentially useful technique, but in demand of more research. The objectives of this work were to evaluate the oviposition non-preference of Bemisia tabaci (Gennadius, 1889) biotype B for different tomato plant genotypes, evaluating the correlation between oviposition preference and pubescence in the genotypes, and analyzing the abaxial and adaxial surfaces of Lycopersicon pennellii leaflets under the scanning electron microscope. Four wild tomato genotypes, LA 716 (L. pennellii); PI 127826 and PI 127827 (L. hirsutum); PI 134417 (L. hirsutum f. glabratum), and two commercial genotypes, Santa Clara and Bruna VFN hybrid (L. esculentum) were evaluated for number of eggs $\mathrm{cm}^{-2}$ in free and nochoice oviposition tests, using randomized block design and completely randomized design, respectively. The number of trichome was measured in $4 \mathrm{~mm}^{2}$ and coefficients of correlation between number of trichomes and number of eggs were calculated. The wild genotypes LA 716 and PI 134417 were less preferred showing oviposition nonpreference resistance type in both tests. The Bruna VFN and Santa Clara were more preferred in free-choice test, while wild genotypes PI 127826 and PI 127827 were more preferred in no-choice test. $L$. pennellii leaflets presented glandular trichomes type IV in both surfaces. Santa Clara genotype presented higher density of trichomes, and $B$. tabaci biotype B presented higher preference to oviposition.

Key words: Lycopersicon spp., insecta, Bemisia tabaci biotype B, plant resistance, trichome

\section{NÃO-PREFERÊNCIA PARA OVIPOSIÇÃO DE MOSCA-BRANCA POR GENÓTIPOS DE TOMATEIRO}

\begin{abstract}
RESUMO: A mosca-branca Bemisia tabaci (Gennadius, 1889) biótipo B é atualmente uma das principais pragas do tomateiro (Lycopersicon spp.). $\mathrm{O}$ uso de plantas resistentes para o controle deste inseto apresentase interessante, com grande potencial para Manejo Integrado de Pragas. Este trabalho teve por objetivos verificar a não-preferência para oviposição de $B$. tabaci biótipo $B$ em genótipos de tomate; avaliar a correlação entre a preferência para oviposição e a pilosidade dos genótipos e analisar a superfície abaxial e adaxial de folíolos de Lycopersicon pennellii em microscópio eletrônico de varredura. Foram utilizados quatro genótipos selvagens, LA 716 (Lycopersicon pennellii); PI 127826 e PI 127827 (L. hirsutum); PI 134417 (L. hirsutum var. glabratum) e dois comerciais, Santa Clara e híbrido Bruna VFN (L. esculentum). Realizaram-se testes com e sem chance de escolha, utilizando para o primeiro o delineamento estatístico em blocos casualizados e para o segundo o delineamento inteiramente casualizado. Em ambos os testes avaliou-se o número de ovos por $\mathrm{cm}^{2}$ de folíolo. Para correlacionar a densidade de tricomas com a oviposição nos genótipos, contou-se 0 número de tricomas em $4 \mathrm{~mm}^{2}$. Os genótipos LA 716 e $\mathrm{Pl} 134417$ foram os menos preferidos para oviposição nos dois tipos de testes, enquanto os comerciais híbrido Bruna VFN e Santa Clara foram os mais preferidos para oviposição em teste com chance de escolha, e os genótipos selvagens PI 127826 e PI 127827 foram os que apresentaram maior número de ovos $\mathrm{cm}^{-2}$ em teste sem chance de escolha. Os folíolos de $L$. pennellii apresentaram, nas superfícies abaxial e adaxial, tricomas glandulares do tipo IV. A quantidade de tricomas em 'Santa Clara' propiciou maior oviposição de Bemisia tabaci biótipo B.

Palavras-chave: Lycopersicon spp., insecta, Bemisia tabaci biótipo B, resistência de plantas, tricomas
\end{abstract}

\section{INTRODUCTION}

Tomato is one of the most consumed fresh vegetables, ranked as number one in the processing industry in Brazil and other countries. Among the states that produce this vegetable in Brazil, the most expressive are Goiás, São Paulo, Minas Gerais, Rio de Janeiro, Rio
Grande do Sul and Espírito Santo (FNP Consultoria \& Comércio, 2001).

Tomato growing is very difficult because of the great number of pests that attack the plants; among them, whiteflies have become a more serious problem since the last decade, after a new biotype (biotype B) was detected in the state of São Paulo (Lourenção \& Nagai, 1994). This

${ }^{1}$ Part of the Thesis of the first author, presented to UNESP/FCAV - Jaboticabal, SP, Brazil. 
new, highly aggressive biotype has caused more intense damage than the biotype previously identified. It presents higher fecundity, a wider range of hosts, and easilyacquired resistance to insecticides (Costa \& Brown, 1990; Prabhaker et al., 1998). Direct damage is a consequence of feeding by adults and nymphs, while indirect damage is represented by the transmission of viruses known as geminiviruses (Brown \& Bird, 1992; Brown, 1994; Carneiro et al., 1999), which have been the crop's most limiting factor in many producing regions (Oliveira \& Farias, 2000), as well as physiological changes such as irregular maturation of fruit (Schuster et al., 1990). The frequent and inadequate use of chemicals has promoted the development of resistance to these products in whitefly populations (Butler et al., 1993). Therefore, the adoption of new control methods will enable achieving population reductions below the economic injury level. Among these methods, the development of resistant varieties through plant breeding is very promising (Eigenbrode \& Trumble, 1994). This method has greater potential for the genus Lycopersicon, which has broad genetic variability which makes feasible see to develop breeding programs targeted at resistance to this pest.

There are several defense mechanisms against pests in tomato plants, namely: Trichome type, chemical substances in some types of trichomes (2-tridecanone, 2-undecanone) and cuticle thickness in the fruit (Williams et al., 1980; Kisha, 1981; Burke et al., 1987; Channarayappa et al., 1992; Heinz \& Zalom 1995 and Liedl et al., 1995). To select tomato genotypes resistant to whiteflies, this project aimed to verify the oviposition non-preference of Bemisia tabaci (Gennadius, 1889) biotype $\mathrm{B}$ for different tomato plant genotypes, evaluating the correlation between oviposition preference and pubescence in the genotypes, and analyzing the abaxial and adaxial surfaces of Lycopersicon pennellii leaflets under the scanning electron microscope.

\section{MATERIAL AND METHODS}

The tests were conducted in a greenhouse in Jaboticabal, SP, Brazil in 1999/2000. The wild genotypes of Lycopersicon pennellii (LA 716), L. hirsutum f. glabratum (PI 134417), L. hirsutum (PI 127826 and PI 127827) were provided by EMBRAPA Hortaliças, BrasíliaDF; the commercial genotypes (L. esculentum) were obtained from the companies Agroflora (Bruna VFN hybrid) and Hortec (Santa Clara open pollination cultivar).

The insects used in the experiments were obtained from a pool of whitefly individuals captured at the Entomology section of Instituto Agronômico de Campinas (IAC). They were kept in cages measuring 2.0 $x 3.0 \mathrm{~m}$ at the bottom, and $2.0 \mathrm{~m}$ in height, manufactured out of an iron frame covered by anti-aphid screen. Soybean, cabbage and drunkard's dream plants were placed inside the cage and replaced as necessary.
Sowing was in expanded polystyrene trays containing agricultural substrate for seedling formation. The wild genotype seeds were treated with $0.05 \%$ captan and with gibberellic acid. Twenty six days after emergence, seedlings were transplanted to $3 \mathrm{~L}$ pots, containing three parts of a typical Typic Haplustox, one part sand and one part compost. Fertilization in the pots was carried out within the levels recommended for the crop after soil analysis (Malavolta, 1981): Basic fertilization (1.5 g simple superphosphate $\mathrm{kg}^{-1}$ soil; $0.3 \mathrm{~g}$ potassium chloride $\mathrm{kg}^{-1}$ soil; $0.3 \mathrm{~g}$ ammonium nitrate $\mathrm{kg}^{-1}$ soil) plus sidedressing ( $0.3 \mathrm{~g}$ ammonium nitrate $\mathrm{kg}^{-1}$ soil, 15 days after transplanting and $0.3 \mathrm{~g}$ ammonium nitrate $\mathrm{kg}^{-1}$ soil, 25 days after transplanting).

Tomato genotypes LA 716, PI 134417, PI 127826, PI 127827, Bruna VFN and Santa Clara were utilized in the free choice test. Each genotype replicate, was kept in a cage similar to those utilized for the whitefly stock rearing, with plants $50 \mathrm{~cm}$ apart from each other. At 30 days of age, each plant was infested with whitefly adults using a mouth aspirator, at the rate of 100 individuals per genotype, (600 insects per cage). Three leaflets from the upper third of the plant and from its apex, the whitefly's preferred oviposition site (Lourenção \& Yuki, 1982; Simmons, 1994) were collected four days after infestation. The number of eggs per leaflet per genotype was counted using a stereoscopic microscope. Each leaflet was then individually measured with a leaf area measuring device calibrated for each operation, which expressed the leaf area value digitally in $\mathrm{cm}^{2}$.

Trials were set up in a randomized block design with six treatments (genotypes) and five blocks (cages). Data were submitted to analysis of variance and means were compared by Tukey test $(P=0.05)$.

To correlate trichome density with oviposition, the number of trichomes in three leaflets was quantified for each genotype in a free choice test. The number of trichomes in a $4 \mathrm{~mm}^{2}$ area on the abaxial surface of each leaflet was counted (Kisha, 1981), using a stereoscopic microscope (50x) equipped with an ocular micrometer. The area was located near the main leaf vein and between the second and third adjacent veins. Data were analyzed using linear correlation.

Leaflets of $L$. pennellii were collected and placed in open Petri dishes kept in covered glass chambers (50 $x 50 \mathrm{~cm}$ ). Cotton wads moistened with $3 \%$ glutaraldehyde in a potassium phosphate buffer at $0.1 \mathrm{~mol} \mathrm{~L}^{-1}$ and $\mathrm{pH} 7.4$ were previously distributed in the dishes. The leaflets were maintained in the chamber for 72 hours and were then post-fixed in osmium tetroxide vapor at $2 \%$. The material was dried for 48 hours in a silica gel desiccator mounted and metalized with a $35 \mathrm{~nm}$ gold-palladium coating in a Denton Vaccum Desk II metalizer, and scanned (JEOL JSM 5410 scanning electron microscope, $15 \mathrm{KV})$.

In the no-choice test each pot containing a plant was protected by a metal cage $40 \mathrm{~cm}$ in diameter and 
$60 \mathrm{~cm}$ in height, lined with voil, and kept in a greenhouse. Thirty-day old plants were artificially infested with whitefly adults that had been confined for four days (Lourenção \& Yuki, 1982). Three leaflets from the upper third of the plant (top) and from its apex were collected per genotype (Simmons, 1994). The number of eggs per leaflet was counted under stereoscopic microscope and then the leaf areas were measured.

A completely randomized design was used, with six treatments (genotypes) and seven replicates (plants). Data were submitted to analysis of variance and means compared using Tukey test $(P<0.05)$.

\section{RESULTS AND DISCUSSION}

\section{Free choice test}

Differences were found in the average number of B. tabaci biotype $\mathrm{B}$ eggs laid on the tomato plant genotypes (Table 1). The least oviposited genotypes were PI 134417 and LA 716, in comparison to the commercial Bruna VFN and Santa Clara, suggesting that those genotypes possess non-preference for oviposition-type resistance. The results found for PI 134417 were also reported by other authors (Berlinger et al., 1983; Fancelli et al., 1999), who classified it as resistant to the pest under consideration. This resistance was associated to the presence of glandular trichomes, which not only have the function of secreting chemical exudates, but also constitute the mechanical basis for resistance (Dimock \& Kennedy, 1983).

Genotypes PI 127827 and PI 127826 did not differ from the other genotypes, thus having an intermediate behavior with regard to the oviposition preference of this pest. Some authors (Gentile et al., 1968; Fancelli et al., 1999) reported PI 127826 as resistant to the whitefly. Even though photoperiod and temperature conditions were not evaluated it can be speculated that these factors might have influenced genotype behavior. Snyder et al. (1998) verified that the resistance of $L$. hirsutum to $B$. tabaci biotype $B$ varied in response to photoperiod. The expression of resistance in certain genotypes can be influenced by multiple factors, such as temperature, photoperiod, and humidity in the air, host and soil, as reported by Lara (1991).

\section{Trichome density}

The tomato genotypes showed differences with regard to the average number of trichomes on the abaxial surface of the leaflets (Table 1). The least pubescent LA 716 and PI 134417 varied from 8.78 to 11.78 trichomes $\mathrm{mm}^{-2}$, respectively; the highest pubescence was shown by Santa Clara (19.22 trichomes $\mathrm{mm}^{-2}$ ), and genotypes PI 127827, Bruna VFN and PI 127826 showed intermediate pubescence.

A positive correlation, indicating that as the number of trichomes increases, the number of eggs laid by B. tabaci biotype B also increases, was found in genotype Santa Clara $\left(r=+0.96^{* *}\right)$. The high trichome density in this genotype favored higher oviposition preference, similar to results obtained in cotton (Berlinger, 1986; Flint \& Parks, 1990), soybeans (McAuslane, 1996) and tomato plants (Heinz \& Zalom, 1995). This happened possibly because the high pubescence provides a more suitable microclimate for oviposition (Butter \& Vir, 1989), and because whitefly females prefer laying their eggs at the insertion base of trichomes (Berlinger, 1986). Therefore, the high density of trichomes in $L$. esculentum was a susceptibility factor to the whitefly, as previously described by Heinz \& Zalom (1995). This high trichome density is probably associated to the higher number of type V non-glandular trichomes, which would make the insect attack easier (Snyder et al., 1998). For the other genotypes, the correlation coefficients were not significant, with values for the commercial genotypes Bruna VFN and PI 127826 at $+0.43^{\mathrm{NS}}$ and $+0.55^{\mathrm{NS}}$, respectively, and for the wild $\mathrm{PI} 127827-0.19^{\mathrm{NS}}$, PI $134417-0.73^{\text {NS }}$ and LA $716-0.77^{\text {NS }}$.

Another factor just as important or even more important than trichome density is the type of trichomes, which was not, however, evaluated in this work. Snyder et al. (1998) verified that the types of trichomes were also responsible, for the whitefly preference for oviposition. Chatzivasileiadis \& Sabelis (1997) also specified trichomes as the most important factor of resistance to pests in the genus Lycopersicon. The wild genotypes of L. hirsutum and L. hirsutm f. glabratum revealed the presence of type I, IV, VI and VII glandular trichomes, whereas for $L$. pennellii, only type IV glandular trichomes

Table 1 - Mean number ( \pm SE) of $B$. tabaci biotype B eggs, mean number of trichomes and their correlations in tomato plant genotypes, in free choice test. Jaboticabal, SP. 1999.

\begin{tabular}{|c|c|c|c|}
\hline Genotype & Mean $^{1,2}$ number of eggs & Mean number of trichomes & Correlation Coefficient $(r)$ \\
\hline & - & - - & \\
\hline PI 134417 & $2.28 \pm 0.68 b$ & $11.78 \pm 2.17 b$ & -0.73 n.s \\
\hline LA 716 & $3.16 \pm 2.14 b$ & $8.78 \pm 3.47 b$ & -0.77 n.s \\
\hline PI 127826 & $7.88 \pm 3.63 \mathrm{ab}$ & $12.62 \pm 5.32 a b$ & +0.55 n.s \\
\hline PI 127827 & $8.72 \pm 1.46 \mathrm{ab}$ & $13.23 \pm 4.48 \mathrm{ab}$ & -0.19 n.s \\
\hline Santa Clara & $17.56 \pm 7.81 \mathrm{a}$ & $19.22 \pm 13.37 a$ & $+0.96^{* *}$ \\
\hline Bruna VFN hybrid & $17.94 \pm 4.61 \mathrm{a}$ & $12.83 \pm 3.76 \mathrm{ab}$ & +0.43 n.s \\
\hline C.V. (\%) & 36.49 & 12.13 & \\
\hline
\end{tabular}

${ }^{1}$ Means followed by a common letter are not different at $5 \%$ by Tukey test.

${ }^{2}$ Original results. For statistical analysis, data were transformed in $(x+0,5)^{1 / 2}$. 
were present (Channarayappa et al., 1992). Aragão et al. (1998) identified, in genotype TOM 556 ( $L$. esculentum), type II + III and V non-glandular trichomes (2590 trichomes $/ \mathrm{cm}^{2} /$ leaf area), type VI glandular trichomes $\left(16 \mathrm{~cm}^{2} /\right.$ leaf area) and type VII glandular trichomes $\left(138 / \mathrm{cm}^{2} /\right.$ leaf area), while for PI 134417 they found type II + III and V non-glandular trichomes (140/ $\mathrm{cm}^{2} /$ leaf area), type I + VI glandular trichomes $\left(843 / \mathrm{cm}^{2}\right)$, type VI glandular trichomes $\left(83 / \mathrm{cm}^{2}\right)$ and type VII glandular trichomes $\left(11 / \mathrm{cm}^{2}\right)$. This is an evidence that there is a higher quantity of glandular-type trichomes in some wild species than in L. esculentum. This fact justify even more strongly the whitefly's non-preference for oviposition in wild genotypes, in comparison to commercial genotypes, consonant with the results obtained in the present work.

The resistance found in LA 716 and PI 134417 is related to the presence of type IV glandular trichomes in the first genotype and to type IV and VI glandular trichomes in the second. These trichomes act as a barrier, preventing oviposition by the whitefly, as observed by Williams et al., (1980) and Channarayappa et al. (1992). This additionally stresses the importance of these materials in controlling $B$. tabaci biotype $B$, since females are more frequently captured by trichomes than males, probably because their ovipositing movements and because they have a longer lifespan (Kisha, 1981), which would help keeping the pest population low.

\section{Scanning electron micrographs of $L$. pennellii}

The scanning electron micrographs of type IV glandular trichomes (Figure $1 \mathrm{~A}$ ) allowed to observe that they measured between $0.2-0.4 \mathrm{~mm}$ in length (Channarayappa et al., 1992; Aragão, 1998), acil-sugars can be found at the tip of the unicellular gland, and bursts when in contact with the insect, capturing it (Liedl et al., 1995) (Figures 1B and 1C). Only type IV glandular trichomes were found in both the abaxial and the adaxial surfaces, as these trichomes are responsible for capturing whitefly adults, which occurred throughout the choice test period, when L. pennellii (LA 716) plants showed their leaflets covered with trapped adults.

\section{No-choice test}

Differences were found in the mean number of whitefly eggs (Table 2); wild genotypes PI 127826 (7.55 eggs $\mathrm{cm}^{-2}$ ) and PI 127827 (4.29 eggs $\left.\mathrm{cm}^{-2}\right)$ were the most oviposited materials. Wild genotype PI 127826 was, therefore, preferred in comparison to the commercial Santa Clara and Bruna VFN. This preference was not detected in the choice test, probably because of a better adaptation of the insect to non-preferential hosts in a nochoice test situation. Adaptation would allow the female to explore new hosts, providing an advantage for the insect under adverse conditions (Blua et al., 1995). In addition, other factors could be interacting and modifying the whitefly's preference, since the confinement conditions are different from those found in free-choice assays. PI 127826 was deemed by Gentile et al. (1968) as having resistance potential because it possesses exudate glandular trichomes, which captured Trialeuroides vaporariorum females, hindering their oviposition. Heinz \& Zalom (1995) showed there is no relationship between trichome density on the leaves of L. hirsutum and the oviposition rate of Bemisia argentifolii.

Among the least oviposited genotypes we could point out PI 134417 (0.47 eggs $\left.\mathrm{cm}^{-2}\right)$ and LA 716 (0.00 eggs $\mathrm{cm}^{-2}$ ), the same being observed by Heinz \& Zalom (1995) and França et al. (1998). For PI 134417, the non-

Table 2 - Mean number ( $\pm \mathrm{SE}$ ) of $B$. tabaci biotype B eggs, in tomato plant genotypes, in no-choice test. Jaboticabal, SP. 1999.

\begin{tabular}{lc}
\hline Genotype & Mean $^{1,2}$ number of eggs $\mathrm{cm}^{-2}$ \\
\hline PI 127826 & $7.55 \pm 1.91 \mathrm{a}$ \\
PI 127827 & $4.29 \pm 1.45 \mathrm{ab}$ \\
Santa Clara & $3.07 \pm 0.65 \mathrm{~b}$ \\
Bruna VFN hybrid & $1.52 \pm 0.35 \mathrm{bc}$ \\
PI 134417 & $0.47 \pm 0.19 \mathrm{c}$ \\
LA 716 & $0.00 \pm 0.00 \mathrm{c}$ \\
\hline C.V. (\%) & 33.57 \\
\hline
\end{tabular}

${ }^{1}$ Means followed by a common letter are not different at $5 \%$ by Tukey test.

${ }^{2}$ Original results. For statistical analysis, data were transformed in $(\mathrm{x}+0,5)^{1 / 2}$.
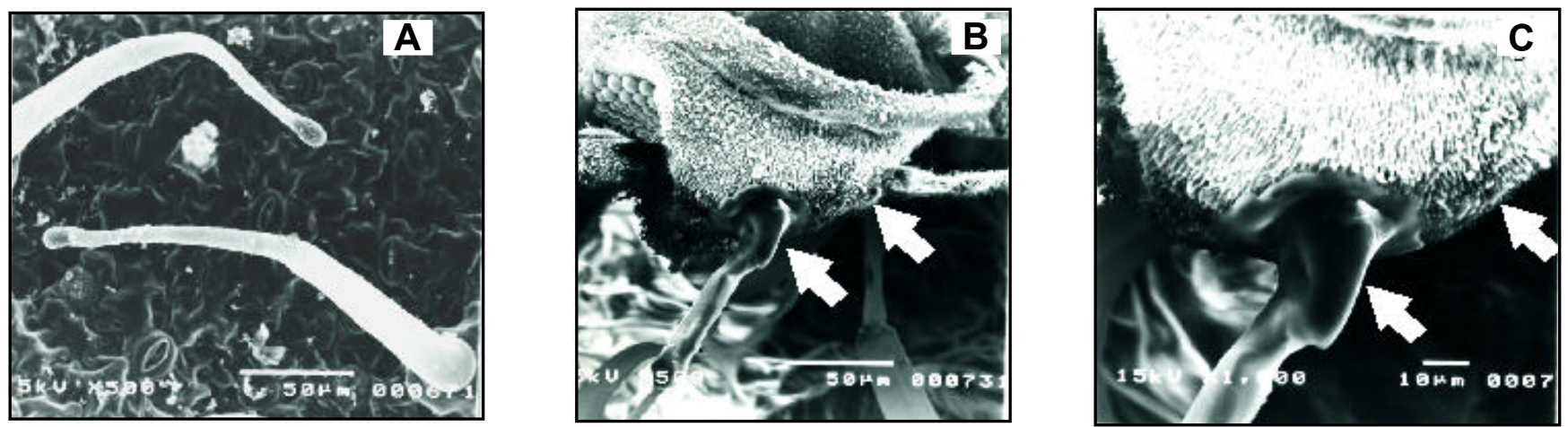

Figure 1 - Scanning electron micrographs of description and capture of $B$. tabaci biotype $B$ by type IV glandular trichome on the abaxial surface of L. pennellii (LA 716): A) type IV glandular trichome; B) captured whitefly; C) trichome attached to whitefly head. Jaboticabal, SP. 999. 
preference for oviposition is related, to the presence of a "natural insecticide" (2-tridecanone) produced by type VI glandular trichomes in the leaves (Williams et al., 1980), whereas Channarayappa et al. (1992) verified an association between density of this type of trichome and physical resistance to the whitefly.

Genotypes LA 716 and PI 134417 showed nonpreference for whitefly oviposition-type resistance in both choice and no-choice tests, and possibly this resistance is associated to the types of trichomes found in these materials. Therefore, the transfer of genes responsible for the presence of these trichomes into commercial cultivars could be valuable in tomato plant breeding programs toward controlling $B$. tabaci biotype $B$.

\section{ACKNOWLEDGEMENTS}

To Fundação de Amparo à Pesquisa do Estado de São Paulo (FAPESP), for granting a doctoral scholarship to the first author, and for financial aid provided (Scholarship Technical Reserve). To Conselho Nacional de Desenvolvimento Científico e Tecnológico (CNPq), for granting a productivity research scholarship to the second author. To EMBRAPA Hortaliças, BrasíliaDF, for providing the wild genotypes, and to the companies Hortec and Agroflora, for the commercial genotypes. To Dr. André L. Lourenção, Setor de Entomologia, Instituto Agronômico de Campinas, IAC, for providing the initial whitefly population; to Dr. Maria Regina Vilarinho de Oliveira from EMBRAPA Recursos Genéticos e Biotecnologia and Dr. Judith K. Brown from Tucson University (USA), for identifying the insects. To Dr. Jaime Maia dos Santos (FCAV/UNESP) for making the scanning electron micrographs.

\section{REFERENCES}

ARAGÃO, C.A. Tricomas foliares associados à resistência ao ácaro rajado Tetranychus urticae (Koch.) em linhagens de tomateiro com alto teor de 2-tridecanona nos folíolos. Lavras, 1998. 69p. Dissertação (Mestrado) Universidade Federal de Lavras.

ARAGÃO, C.A.; GAVILANES, M.L.; DANTAS, B.F.; MALUF, W.R.; BENITES, F.R.G. Classificação e quantificação de tricomas foliares em duas espécies de tomateiro. In: CONGRESSO NACIONAL DE BOTÂNICA, 49., Salvador, 1998. Resumos. Salvador: Sociedade de Botânica do Brasil, 1998. p.24.

BERLINGER, M.J. Host plant resistance to Bemisia tabaci. Agriculture, Ecosystems and Environment, v.17, p.69-82, 1986.

BERLINGER, M.J.; DAHAN, R.; SHEVACH-URKIN, E. Breeding for resistance in tomato to the tobacco whitefly, Bemisia tabaci. Phytoparasitica, v.11, p.132, 1983.

BROWN, J.K. Current status of Bemisia tabacias a plant pest and virus vector agroecosystems worldwide. Plant Protection Bulletin, v.42, p.3-32, 1994.

BROWN, J.K.; BIRD, J. Whitefly-transmitted geminiviruses and associated disorders in Americas and the Caribbean Basin. Plant Disease, v.76, p.220-225, 1992.

BLUA, M.J.; YOSHIDA H.A.; TOSCANO, N.C. Oviposition preference of two Bemisia species (Homoptera:Aleyrodidae). Population Ecology, v.24, p.88-83, 1995

BURKE, B.A.; GOLDSBY, G.; MUDD, J.B. Polar epicuticular lipids of Lycopersicon pennellii. Phytochemistry, v.26, p.2567-2571, 1987.

BUTLER JR., G.D.; HENNEBERRY, T.J.; STANSLY, P.A.; SCHUSTER, D.J. Insecticidual effects of selected soaps and detergents on the sweet potato whitefly (Homoptera: Aleyrodidae). Florida Entomologist, v.76, p.161170, 1993.

BUTTER, N.S.; VIR. B.K. Morphological basis of resistance in cotton to the whitefly Bemisia tabaci. Phytoparasitica, v.17, p.251-261, 1989.
CARNEIRO, J.S.; HAJI, F.M.P.; BLEICHER, E.; SILVA, S.H.P; ALENCAR, J.A.; ARAUJO, L.H.A.; BARBOSA, F.R. Uma proposta de manejo-1. A Granja, v.606, p.24-25, 1999.

CHANNARAYAPPA, S.G.; MUNIYAPPA, V.; FRIST, R.H. Resistance of Lycopersicon species to Bemisia tabaci, a tomato leaf curl virus vetor. Canadian Journal of Botany, v.70, p.2184-2192, 1992.

CHATZIVASILEIADIS, E.A.; SABELIS, M.W. Toxicity of methyl ketones from tomato trichomes to Tetranychus urticae Koch. Experimental \& Applied Acarology, v.21, p.473-484, 1997

COSTA, H.S.; BROWN, J.K. Variability in biological characteristics, isozyme patterns and virus transmission among populations of Bemisia tabaci in Arizona. Phytopatology, v.80, p.888, 1990.

DIMOCK, M.; KENNEDY, G. The role of glandular trichomes in the resistance of Lycopersicon hirsutum f. glabratum to Heliothis zea. Entomologia Experimentalis et Applicata, v.44, p.263-268, 1983.

EIGENBRODE, S.D.; TRUMBLE, J.T. Host plant resistance to insects in integrated pest management in vegetable crops. Journal of Agriculture Entomology, v.11, p.201-224, 1994.

FANCELLI, M.; VENDRAMIM, J.D.; LOURENÇÃO, A.L. "Screening" de genótipos de tomateiro para resistência a Bemisia tabaci biótipo B. In: ENCONTRO LATINO-AMERICANO E DO CARIBE SOBRE MOSCAS BRANCAS E GEMINIVIRUS, 8., Recife, 1999. Resumos. Recife: IPA, 1999. p.156.

FLINT, H.M.; PARKS, N.J. Infestation of germplasm lines and culitvars of cotton in Arizona by whitefly nymphs (Homoptera, Aleyrodidae). Journal of Entomology Science, v.25, p.223-229, 1990.

FNP CONSULTORIA \& COMÉRCIO. Agrianual 2001. São Paulo, 2001. p.513524.

FRANÇA. F.H.; VILLAS BÔAS, G.L.; PESSOA, H.B.S.V.; GIORDANO L.B. Avaliação de tomate para resistência à Bemisia argentifolii. In CONGRESSO BRASILEIRO DE ENTOMOLOGIA, 17., Rio de Janeiro, 1998. Resumos. Rio de Janeiro: UFRRJ, 1998. p.89.

GENTILE, A.G.; WEBB, R.E.; STONER, A.K. Resistance in Lycopersicon and Solanum to Greenhouse whiteflies. Journal of Economic Entomology, v.61, p.1355-1357, 1968

HEINZ, K.M.; ZALOM, F.G. Variation in trichome-based resistance to Bemisia argentifolii (Homoptera: Aleyrodidae) oviposition on tomato. Journal of Economic Entomology, v.88, p.1494-1502, 1995.

KISHA, J.S.A. Observations on the trappings of the whitefly Bemisia tabaci by glandular hairs on tomato leaves. Annals of Applied Biology, v.97, p.123-127, 1981

LARA, F.M. Princípios de resistência de plantas a insetos. 2.ed. São Paulo: Ícone, 1991. 336p.

LIEDL, B.E.; LAWSONN, D.M.; WHITE, K.K.; SHAPIRO, J.A.; COHEN, D.E.; CARSON, W.G.; TRUMBLE, J.T.; MUTSCHLER, M.A. Acylsugars of wild tomate Lycopersicon pennellii alters settling and reduces oviposition of Bemisia argentifolii (Homoptera: Aleyrodidae). Journal of Economic Entomology, v.88, p.742-748. 1995.

LOURENÇÃO, A.L.; YUKI, V.A. Oviposição de Bemisia tabaci (Genn.) (Homoptera: Aleyrodidae) em três variedades de soja sem chance de escolha. Bragantia, v.41, p.199-202, 1982.

LOURENÇÃO, A.L.; NAGAI, H. Surtos populacionais de Bemisia tabaci no Estado de São Paulo. Bragantia, v.53, p.53-59, 1994.

MALAVOLTA, E. Manual de química agrícola: adubos e adubação. 3.ed. São Paulo: Agronômica Ceres, 1981. 509p.

McAUSLANE, H.J. Influence of leaf pubescence on ovipositional preference of Bemisia argentifolii (Homoptera, Aleyrodidae) on soybean. Environmental Entomology, v.25, p.834-841, 1996.

OLIVEIRA de, M.R.V.; FARIAS, M.R. Pragas: A mosca-branca assusta produtores e pesquisadores. A Granja, v.56, p.12-24, 2000.

PRABHAKER, N.; TOSCANO, N.C.; HENNEBERRY, T.J. Evalution of insecticide rotations and mixtures as resistance management strategies for Bemisia argentifolii (Homoptera: Aleyrodidae). Journal of Economic Entomology, v.91, p.820-826, 1998.

SCHUSTER, D.J.; MUELLER, T.F.; KRING, J.B.; PRICE, J.F. Relationship of the sweetpotato whitefly to new tomato fruit disorder in Florida. HortScience, v.25, p.1618-1620, 1990.

SNYDER, J.C.; SIMMONS, A.M.; TRACKER, R.R. Attractancy and oviposition response of type IV trichome density on leaves of Lycopersicon hirsutum grown in three day-lenght regimes. Journal of Entomology Science, v.33, p.270-281, 1998.

SIMMONS, A.M. Oviposition on vegetables by Bemisia tabaci (Homoptera: Aleyroidae): temporal and leaf surface factors. Environmental Entomology, v.23, p.381-389, 1994.

WILLIAMS, W.G.; KENNEDY, G.G.; YAMAMOO, R.T.; THACKER, J.D. BORDNER, J. 2-tridecanone: A naturrally ocorring inseticide from the wild tomato Lycopersicon hirsutum f. glabratum. Science, v.207, p.888-889, 1980

Received November 21, 2001 